\title{
ミトコンドリア酸化系酵素・モノアミンオキシダーゼ（MAO）の基質選択性と アミン代謝
}

\author{
東北薬大 ○櫻井栄一, 野村明生, 山崎誠治, 引地 登, \\ 東北大・医櫻井映子 \\ 愛媛大・医前山一隆 \\ ウプサラ大・医Ｓukhwinder S. Jossan, Lars Oreland
}

METABOLISM OF AMINES BY MITOCHONDRIAL MONOAMINE OXIDASE AND SUBSTRATE SELECTIVITY

Ei ichi Sakurai, Akio Nomura, Seiji Yamasaki, Noboru Hikichi, Eiko Sakurai ${ }^{1)}$, Kazutaka Maeyama ${ }^{2)}$, Sukhwinder S. Jossan ${ }^{32}$ and Lars Oreland ${ }^{3)}$

Tohoku College of Pharmacy, ${ }^{1)}$ Tohoku University School of Medicine, ${ }^{2)}$ Ehime University School of Medicine, ${ }^{3)}$ Uppsala University School of medicine (BMC)

【目的】モノアミン酸化酵素（MA0）は生体内臟器中に広く分布し, 細胞内では主としてミト コンドリア外膜に結合して存在している．MAOは補酔素としてFADをもっており, 多くの脂肪族あ るいは芳香族アミンを酸化的に脱アミノ化し，アルデヒドへと変換する.この反応はP450によっ て触媒される酸化反応と区別される.また，MAOは二つの違った夕イプ, すなわちモノアミン酸 化酵素の特異的阻害剂であるクロルジリンの低濃度で抑制される A夕イプとデプレニルの低濃度 で抑制されるB夕イプがあり, 近年クローニングにより構造が決定されている. また，これら両 タイプのMAOは阻害剂感受性のほかに, 基質特異性がある. 本研究では特に脳を中心として, モ ノアミン酸化酵素の局在と代謝回転, モノアミン酸化醅素の脳内分布とアミン代謝の相関性, M A0の種族あるいは系統間の差, および生理的加龄による変化を検討した。 また，これらMA0の性 質から基質に対する選択性とアミン代謝について，生理活性アミンをはじめとして，1-Methy14-pheny1-1,2, 3,6-tetrahydropyridine（MPTP)を用いて検討した. さらに, われわれのもう一つ の研究テーマである光学異性体薬物の立体選択的体内動態に関して,アミン化合物のMAOによる 酸化的脱アミノ化に対するキラル認識についても検討を加えた。

【実験方法・結果・考察】

1. MAO-Bの局在と代謝回転

${ }^{11} \mathrm{C}-\mathrm{L}$-デプレニルを合成し, in vitro オートラジオグラフィーを用いてヒト脳における

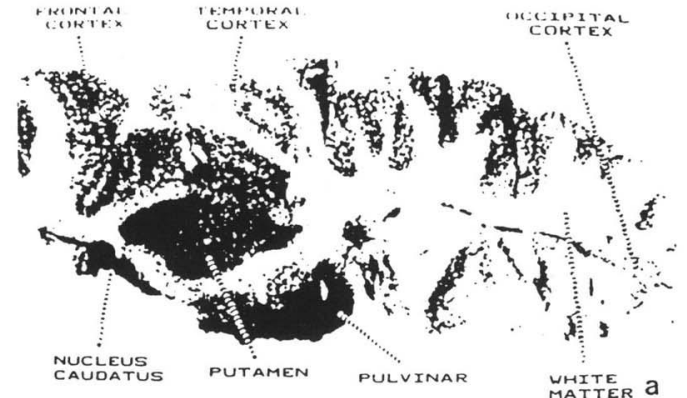

Fig. I Localization of monoamine oxidase in human brain by autoradiographical use of ${ }^{11} \mathrm{C}$-labelled L-deprenyl

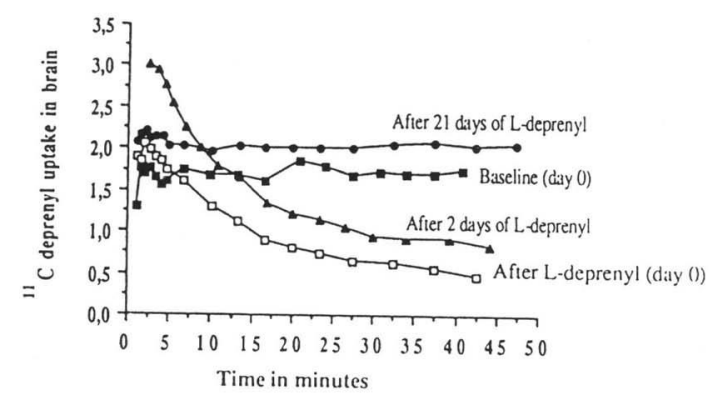

Fig. 2 Turnover of monoamine oxidase $B$ in pig brain by positron emission tomography using ${ }^{~ "} \mathrm{C}$-labelled $\mathrm{L}$-deprenyl 
${ }^{11} \mathrm{C}-\mathrm{L}-$ デプレニルの結合を観察したところ, 尾状核・被款, 視床, 黒質に高いbindingが認め られた。これに対し大脳皮質と白質においては高い結合は見られなかった（Fig. 1). さらに,ブ夕脳におけるMA0-Bの代謝回転速度を ${ }^{11} \mathrm{C}-\mathrm{L}-$ デプレニルをリガンドにPositron emission tomography（PET）にて測定したところ，その半減期は6.5日となった。（Fig. 2）.

\section{MAO活性の分布と生体内アミン代謝との関係 ${ }^{1)}$}

ラット脳各部位（8部位）におけるIntra- and extra-synaptosomal MA0活性をセロトニン (5-HT)およびドパミン(DA)を用いた低基質濃度法で測定した. その結果，Intra-5-HT-

MAOは視床下部と線状体で高い活性を示した。また，Intra-DAMA0-Aおよび-Bの活性はともに線状 体で顕著に高かった．さらに，セロトニンを基質としてMA0-Aを， $\beta$-フェニルエチルアミンを基 質としてMA0-Bをradiometricな方法で測定したところ, 両夕イプのMA0活性とも視床下部, 扁桃 核, 線状体の順に活性が高く, MA0-A/-B比は約1.6と算出された。同様に, 脳を 8 分画しセロ トニンとその代謝物5-hydroxyindole acetic acid(5-HIAA)さらにドパミンおよびその代謝物3, 4-dihydroxyphenylacetic acid(DOPAC)をHPLC-ECD法にて測定し, 前述したMAO活性との相関性を 求めた. Table 1からわかるように, MAOと生体内アミンの代謝物, さらにはモノアミン取り込み 速度亡MA0活性, 各アミン濃度との間に高い相関係数が得られ, 中枢神経系においてMA0がモノア ミンの種類を選択的し，その代謝を調節していることが示唆された。

Table 1.

Correlation coefficients between various MAO activities and serotonin or dopamine uptake rates, transmitters and their metabolites concentrations in different regions of the rat brain

\begin{tabular}{lccccccccc}
\hline & $\begin{array}{c}\text { MAO } \\
\text { Intra-5-HT }\end{array}$ & $\begin{array}{r}\text { MAO-A } \\
\text { Intra-DA }\end{array}$ & $\begin{array}{c}\text { MAO-B } \\
\text { Intra-DA }\end{array}$ & MAO-A & MAO-B & $\begin{array}{c}5-H T \\
\text { conc. }\end{array}$ & $\begin{array}{c}5-H I A A \\
\text { conc. }\end{array}$ & $\begin{array}{c}\text { DA } \\
\text { conc. }\end{array}$ & $\begin{array}{c}\text { DOPAC } \\
\text { conc. }\end{array}$ \\
\hline 5-HT uptake & $0.98^{* * *}$ & - & - & $0.84^{*}$ & $0.70+$ & $0.71^{*}$ & $0.68 \dagger$ & - & - \\
DA uptake & - & $0.99^{* * *}$ & $0.87^{* *}$ & 0.15 & -0.04 & - & - & $0.99^{* * *}$ & $0.99^{* * *}$ \\
Intra 5-HT MAO & - & - & - & $0.88^{* *}$ & $0.76^{*}$ & $0.73^{*}$ & $0.65 \dagger$ & - & - \\
Intra DA MAO-A & - & - & $0.89^{* *}$ & 0.21 & 0.02 & - & - & $0.99^{* * *}$ & $0.99^{* * *}$ \\
Intra DA MAO-B & - & - & - & 0.57 & 0.34 & - & - & $0.86^{* *}$ & $0.86^{* *}$ \\
MAO-A & - & - & - & - & $0.92^{* *}$ & 0.62 & 0.50 & 0.15 & 0.16 \\
MAO-B & - & - & - & - & - & 0.60 & 0.31 & -0.02 & -0.02 \\
5-HT conc. & - & - & - & - & - & - & $0.67 \dagger$ & - & - \\
DA conc. & - & - & - & - & - & - & - & - & $0.99^{* * *}$ \\
\hline
\end{tabular}

Abbreviations: Intra-5-HT MAO = intra-serotonin-synaptosomal MAO activity; intra-DA MAO-A = DA oxidation by intra-DA-synaptosomal MAO-A; intra-DA MAO-B = DA oxidation by intra-DA-synaptosomal MAO-B; 5-HT= serotonin; DA = dopamine.

Correlation coefficients: $\cdots P<0.001,{ }^{* *} P<0.01,{ }^{*} P<0.05,+P<0.1$.

\section{3 . 種族あるいは系統間のMAO活性の違い, および生理的加齢による変化 ${ }^{2)}$}

MA0の種族（NMRIマウス, Sprague Dowleyラット，サル，ヒトによる活性の違いを線状体におい て検討した。 その結果, マウスとラットとの間にそれほど大きな差は認められなかったが, サル においてはMA0のAタイプの活性は測定されず, MA0-Bの活性のみか観察された。また，七トの場 合マウスやラットと異なりMA0-BがMA0-A活性より高く, MA0-A/-Bの比は逆転していた.

系統間の差についてはマウスのみNMRI とC-57 b1間で，また生理的加龄による変化については マウスとラットについて検討したが, その詳細についてはMPTPの代謝との関係において後述する。

\section{MAO-Bの活性がMPTP代謝（脱水素化）のための律速段階となり得るか? ${ }^{3)}$}

MPTPは脳に取り込まれると, グリア細胞のMA0-Bによって酸化され，1-methyl-4phenylpyridinium ion (MPP+) になることが知られている.生成したMPP+はドパミン取り込み 部位から能動的にドパミン性神経細胞に取り込まれ，選択的な神経毒性を示すので, ドパミン取 り込み速度を測定することによりMPP+の取り込み量を十分説明することが可能である. 本研究で はMA0-B活性のバリエーションがMPTPの神経毒性によ゙のように関わってくるかについて，それぞ れの条件下のMAO-B活性を直接测定し, ドパミン取り込み速度の测定值を指標にして検討した。

1) デプレニルによるMAO-B活性の抑制とMPTPによるドパミン取り込み速度の変化 
C-57 blおよびNMRI雄性マウス（1 2 週齿）による検討：MPTPを50 mg/ $/ \mathrm{kg}$ i.p. 投与 12 時間前 に, MAO-Bの選択的抑制薬デプレニル $(0.02-5.0 \mathrm{mg} / \mathrm{kg})$ をC $-57 \mathrm{bl}$ マウスに一回腹腔内投与し, 線条体におけるMAO-B活性の抑制の程度とMPTPによるドパミン取り込み速度変化の関係を検討し た. その結果, MAO-B活性抑制の程度が低い場合, MPTPによる毒性を有意に軽减しなかった。し かし, MAO-B活性の抑制の程度が4 $0 \%$ を越えると, ドパミン取り込み速度が上昇し始め, 約 $60 \%$ MA0-B活性の抑制ではMPTPによるドパミン取り込み速度の減少を完全に防ぐことができ た.また, NMRIマウスにおいてもほぼ同様の結果が観察された。

2 ) 生理的加秢による検討

C-57 bl, NMRI マウスおよびSprague Dowleyラットの線条体におけるMA0-B活性は加秢に伴い上 昇し, 特に生後 10 日亡 3 週目の間に大き な増加が認められた。このことから両マウ スにおいての加齢に伴うMAO-Bの活性の上昇 はMPTPによるドパミン取り込み速度を減少 させることが示唆された. ラットでこのよ うな関係は認められなかった。しかし， MAO-Bはドパミン・シナプトゾーム外膜に局 在しているため, 加㱓に伴うMAO-B活性の上 昇はドパミンが再取り込みされる（われわれ の実験からドパミン取り込みも加龄により上 昇することが認められている。）過 Fig. 3

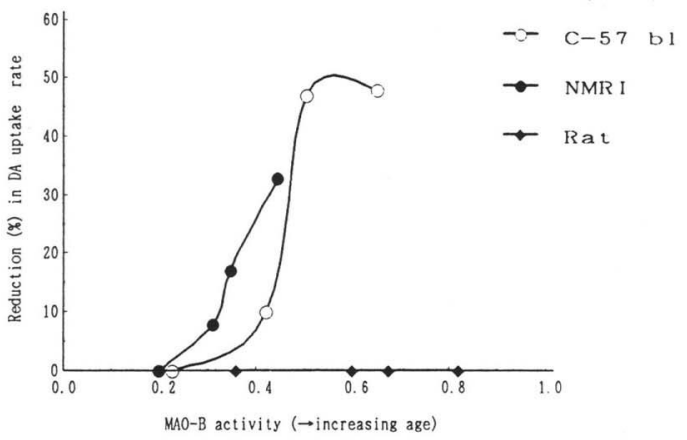
程で過酸化水素の生成を促進し，OH MAO-B activities with increasing age in the brains of rat and two strains mice ラジカルの反応性を高めている可能性がある（Fig. 3).これら結果亡 1 ) のデータからは, MPTPの神経毒性の発現にMA0-Bの活性は必要ではあるが, MAO-BはMPTPのMPP+への変換のための律 速酵素とはなり得ないことが示唆された。

一方, 線条体におけるMA0-Aの活性の変化は，10日，3週，12 週秢においてC-57 b1, NMRIマウスおよびSprague Dowleyラットでいずれも大きな変動は認められなかったが，40週齿 のマウスではC-57 blで $40 \%$, NMRIで $60 \%$ の減少が認められた. ドパミン・シナプトゾーム はおもにMA0のA型を含んでいるため, 老齢化によるMA0-Aの減少は過酸化水素の生成を抑え, O Hラジカルの発生を低下させることが考えられ，老齢におけるこの作用は，MAO-Bのそれとは相 反する方向に働くのではないかと推測される．しかし，ラットの場合には，加齢に伴うMAO-Aの 活性に有意な変化はなかった。

\section{N-tele-メチルヒスタミンの代謝}

ヒスタミン・ニューロン内において, ヒスタミンはヒスタミンN-メチル基転位化酵素により N-tele-メチルヒスタミンとなるが, これがMA0-Bにより1-methyl-4-imidazole acetic acidに代 謝される．本研究では，ヒスタミンの遊離と合成を調節するpresynaptic autoreceptor・H3受容 体の特異的アゴニスト・ $\alpha$-メチルヒスタミン とアンタダニスト・チオペラミド5) がMA0活性に どのような影響をおよぼすかについて検討した。その結果, N-tele-メチルヒスタミンの

N-tele-メチルイミダゾール䣷酸への変換は，チ才ペラミドによって競合的に抑制された．また， この結果とは対照的に $\alpha$-メチルヒスタミンのMA0-Aおよび-Bに対する抑制効果は僅かなものであ った ${ }^{6}$ ).

6.クロルフェニラミンのMAOによる酸化的脱アミノ化の立体選択性

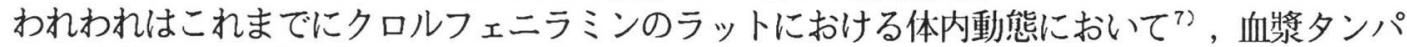
クへの結合やラット肝CYP2C11によるN-脱メチル化にキラル識別があることを見いだした．MA0は 基質亡して第一級モノアミンや第二級および第三級モノアミン類を代謝することから, クロルフ ェニラミンはMAOO基質になり得る可能性が十分にある. しかも, この薬物は脳への移行性が大 
きく，モノアミン代謝へも影響をおよぼすが，その作用には立体特異性があることを報告してき た ${ }^{8.9)}$. 本研究ではラット脳ミトコンドリア分画を調製し, クロルフェニラミンのMAOによる代 謝を検討した。 その結果，クロルフェニラミンは脳内モノアミン酸化酵素により酸化的に脱アミ ノ化されることが認められた。しかし，アルデヒド体の生成はd-体と1-体との間に有意な差が見 られなかった，さらに，クロルジリンおよびデプレニルによる抑制作用を検討したところ，デプ レニルによっては完全に脱アミノ化がd-体，1-体とも抑えられた．しかし，クロルジリンの添加 によりd-体の酸化反応は約 $50 \%$ 抑制されたが, 1-体の場合, その阻害効果はほとんど認められな かった。

以上のように, 中枢性ミトコンドリアMAOによるアミン代謝と基質選択性について検討した が, MAOはうつ病, パーキンソン病など様々な精神神経疾患の発症と深く関わっており, 現在は さらに，銅およびピリドキサルリン酸を補酵素とする血漿MAO ${ }^{10}$.11) と脳MAOとの関連性を明らか にしながら，病態解明に役立てて行きたいと考えている。

Abstract We studied the metabolism of amines by mitochondrial monoamine oxidase (MAO) and substrate selectivity in mammalian brain. The following conclusions were obtained. 1) The regional distribution of MAO-B in human brain by autoradiographical use of ${ }^{11} \mathrm{C}-\mathrm{L}$-deprenyl was high in the caudate nucleus, putamen, thalamus, substantia nigra. The half-life for the turnover rate of $\mathrm{MAO}-\mathrm{B}$ in pig brain by positron emission tomography using ${ }^{11} \mathrm{C}$ - $\mathrm{L}$-depreny1 was calculated to be 6.5 days. 2) Relation between serotonin and dopamine uptake rates, monoamine concentrations and MA0 activities were estimated in various regions of rat brain. Of main interest is the finding that MAO activities in general (conventional method) were positively correlated to seroton in uptake rates and to intra-5-HT-synaptosomal MAO, but not to dopamine uptake rates or intra-DA-synaptosomal MAO activities. 3) An inhibition of MAO-B of more than $40 \%$ was required to reduce the MPTP toxicity and it was completely prevented at about $60 \%$ MAO inhibition. Moreover, although MPTP toxicity in relation to age, dopamine up take and MAO activity was investigated in two rodent species, MAO-B activity was not the rate-limiting step for MPTP neurotoxicity. 4) Histamine H3-ligands inhibited the conversion of $\mathrm{N}$-tele-methylhistamine to $\mathrm{N}$-tele-methylimidazoleacetic acid by MAO-B in the rat brain. 5) The oxidation of racemic chlorpheniramine was catalyzed by mitochondrial MAO of rat brain. Moreover, there was a stereoselective difference in oxidative deamination of chlorpheniramine by MAO-A and - B.

References 1) E. Sakurai, S. Yamasaki, H. Niwa, S.S. Jossan, J. Hallmann, L. Oreland., Biogenic Amines, 7, 1-10 (1990). 2) S. S. Jossan, E. Sakurai, L. Oreland, Pharmacol. Toxicol. 64, 314-318 (1989). 3) S. S. Jossan, E. Sakurai, L. Oreland, Biogenic Amines, 4, 371-379 (1987). 4) S. Yamasaki, E. Sakurai, N. Hikichi, N. Sakai, K. Maeyama, T. Watanabe, J. Pharm. Pharmacol., 46, 371-374 (1994). 5) E. Sakurai, E. Gunji, Y. Iizuka, N. Hikichi, K. Maeyama, T. Watanabe, J. Pharm. Pharmacol., 46, 209-212 (1994). 6) E. Sakurai, E. H. Sakurai, K. Maeyama, T. Watanabe, S.S. Jossan, L. Oreland, Biochem. Pharmacol, in press (1994). 7) E. Sakurai, S. Yamasaki, Y. Iizuka, N. Hikichi, H. Niwa, J. Pharm. Pharmacol., 44, 44-47 (1991). 8) E. Sakurai, S. Yamasaki, N. Hikichi, K. Onodera, Jpn. J. Psychopharmacol., 11, 237-244 (1991). 9) E. Sakurai, S. Yamasaki, N. Hikichi, K. Onodera, Tohoku J. Exp. Med., 163, 239-244 (1991). 10) J. Hallman, E. Sakurai, L. Oreland, Acta Psychiatr. Scand. 81, 73-77, 1990.

11) E. Sakurai, Eri Gunji, Y. Iizuka, N. Hikichi, K. Maeyama, T. Watanabe,

J. Pharmacol. Methods, 29, 105-109 (1993). 